\title{
Mass Media Exposing Representations of Reality Through Critical Inquiry
}

Marvin Starominski-Uehara, PhD

Risk Management Consultant, Japan

muehara79@gmail.com

\begin{abstract}
The covid-19 pandemic has brought to fore the key role that mass media plays in shaping collective risk perception. This paper looks at the inquiry process carried out by Brazilian journalists covering the first public interview of a newly appointed Health Minister. It bases this analysis on the precept of 'a priori intuition' by Immanuel Kant in 'Critique of Pure Reason'. The paper argues that, contrary to common sense, journalists can more accurately shape representations of reality, while clarifying authorities' statements, by arbitrarily depriving themselves from prior knowledge and relying, instead, on personalizing space and time in the inquiry process.
\end{abstract}

Keywords: covid-19; journalism; Kant; discourse analysis; Brazil; critical inquiry

\section{Introduction}

Brazil is a sui generis case in this unprecedented global health crisis. It has been dealing with a sanitary crisis and a heightened political one at the same time (Prado, 2020). Daily news are intertwined by political clashes and the tallying of deaths for the novel coronavirus (SARS-cov-2). Journalists in the country generally agree that covering the sanitary crisis should prevail in the mainstream media (Gomes, 2020). Nonetheless, the political drama the country is engulfed in yields appealing commercial headlines while many people are at home eager for information on the epidemic and how politics might affect its development. This paper argues that, beyond the need to generate audience traction for commercial purposes, the primary role of the mass media in times of uncertainty is helping viewers and readers unravel conflicting narratives by challenging unscrupulous rewards of confirmation bias (Klayman, 1995) and exposing the benefits of triggering cognitive dissonance (Knobloch-Westerwick \& Kleinman, 2012). 
Shaping reality by personalizing the representation of uncertainty is the strategy used by the Brazilian president to enforce his agenda. The president has demanded the end of isolation and social distancing to contain the spread of the novel coronavirus by claiming that the economic crisis these preventive measures ensue to be worse than the epidemic itself (Ribeiro, 2020). Such a dichotomy, or fallacy, intentionally discounts the efficacy of non-pharmaceutical measures in reducing and even temporarily eliminating the rates of transmission for this pathogen (Ferguson et al., 2020). It also deliberately conceals the ingrained fear of the president and his entourage that an economic downturn will have on the chances of securing a new mandate. Responding to this fear, the president has repeatedly downplayed i) the severity of this disease (Congresso Em Foco, 2020); ii) the effectiveness of mitigation measures to slow down the rates of infection (Behnke, 2020) and iii) used every opportunity to consistently convey his particular perception of reality (Folha de S. Paulo, 2020a).

One of the president's communication strategies to seek support and seed discord is painting a fatalistic picture of this crisis (Brandão, 2020). He states that he himself as well his close relatives are also at risk of falling ill and perishing from this disease (Weterman, 2020). Such 'personal' risk is genuinely false. The circumstances that the president and his relatives find themselves in are diametrically opposed to the state of millions of people living under the poverty line. There are also several examples that containment and mitigation measures can effectively break the chains of infection if they are planned, coordinated and implemented accordingly. These examples have been purposefully omitted by the federal government as it risks exposing the lack of preparedness (O Globo, 2020), dysfunctionality (IstoÉ, 2020) and inability of the current administration in dealing with this sanitary crisis (Picheta \& Siad, 2020).

The appointment of a new Health Minister to design and coordinate the national strategy against the novel coronavirus highlights the political instability in the country. On April 22nd, 2020, five days after taking office, the new minister gave his first public interview (UOL, 2020). This briefing lasted for nearly ten minutes followed by three questions. The objective of this briefing was to outline the new strategy of the federal government to address the epidemic and 
demonstrate alignment to the president's representation of reality. The decision to select this event to analyze the role of public inquiring in shaping collective risk perception lies in the significance of this case. The Brazilian society longed to hear from the highest health authority how the federal government planned to reduce the rates of infection, treat the infected, and gradually reopen the economy. This first briefing is also particularly important because it sets the expectation over the ability of the new minister to adequately manage this public health crisis. Journalists covering this briefing were expected to ask unbiased questions that would help the public at large grasp uncertainty and assess the risk of this pathogen to their wellbeing.

\section{Theoretical Framework}

Journalism is one of the pillars of democracy (Barnett, 2009). Journalists conceptualize freedom by uncovering the intricacies of pivotal political events (Bardoel \& d'Haenens, 2004). Their work feeds individuals with information that shapes the way a predicament is appreciated (Caple \& Bednarek, 2013). Journalists, however, are not always exempt from biases (Starkey, 2006). Reporters covering the work of public authorities often frame their questions based on the orientation of their employers (Van Dalen, 2012).

The risk of framing inquiry processes is depriving society from reliable empirical evidence juxtaposed in conflicting narratives. The mass media is understood to have commercial interests in a competitive environment to not challenge some political views (Albarran, 2008). They often gain access, rights and increase their revenues if they decide to follow the status quo (Street, 2010:179). The downside of such an approach is the eroding of the critical thinking ability of the general population to assess the risks of a crisis to their life and routine (Durfee, 2006). The mass media and its journalists, therefore, are expected to not shy away from challenging assumptions and premises behind political narratives. Media networks that foster resourceful debates and are not afraid of incurring the costs of shifting opinions after the emergence of conflicting evidence benefits from increasing levels of perceived trust and credibility (Williams, 2012). 
Journalists seeking the truth in developing stories also face the challenge of keeping abreast of the latest news and facts during critical times. It is believed that well-informed journalists are in position to craft more insightful questions (Nisbet, \& Fahy, 2015). This paper argues the opposite. Assuming that i) memory is bounded and selective, thus fallible (Pluviano, 2019); ii) the digital era of knowledge production is subject to biases and hidden agendas (Fisher, 2018), particularly in times of crisis and uncertainty (van Zoonen \& van der Meer, 2015); and iii) the representation of reality relates to personal experience (Lear, 2017), this paper posits that inquiry processes aimed at effectively exposing contradictions, incoherences and shallow thinking in public statements should focus on personalizing questions that reveal interviewee's perceptions of space and time. That is, journalists are more likely to gather valuable information to their network and the public alike by crafting straightforward questions based on fundamental cognitive traits that invoke past experiences, which help uncover the order, susceptibility and predisposition of an individual's thoughts, beliefs and interests.

Immanuel Kant in 'Critique of Pure Reason' proposes that our minds are subjected to forms of space and time. Space and time are sine qua non for our experiences and thus essential to understand how we gain knowledge and develop insights into how our mind works (Brook, 2010). Space and time for Kant are moving objects (Allison, 2006). This means that we only have a vague idea, or 'a priori intuition', of how our particular notions of space and time shape our representations of the world (Merritt, 2010). That is, space and time are i) not entirely dependent on our own personal experiences; ii) they are unique in the sense that they are private and change over time; and iii) recent memories and close events seem to carry more weight in our decisions (Janiak, 2009). This paper, therefore, proposes the instrumental use of these cognitive elements to help journalists craft questions that expose how the experience of authorities shape their representations of reality and the weight of intuition in their decisions. Kant states that the knowledge of the language in which the communication between the parties occur is enough to carry out this critical analysis (McLaughlin \& Schlaudt, 2020). The expectation of resorting to Kant's cognitive studies is steering away political debates from trivial 
and manufactured representations found in performative and rhetorical disputes that promote misinformation and may put lives unnecessarily at risk.

It is worth noting that this paper taps into Kant's ideas of space and time as a form to guide inquiry processes during uncertain times. It is not the purpose of this paper to engage in a philosophical debate over i) the interpretations of 'Critique of Pure Reason' (Strawson, 2018); ii) the origins and place of Kant in Western philosophy (Wood, 2007); or iii) review his extensive work (Scott, 2016). The motivation in resorting to Kant's transcendental idealism is the understanding that his studies on metaphysics can contribute to the assessment of how public authorities represent reality and how professionals in the communication sector could make use of cognitive psychology to gather valuable information during challenging times.

Figure 1

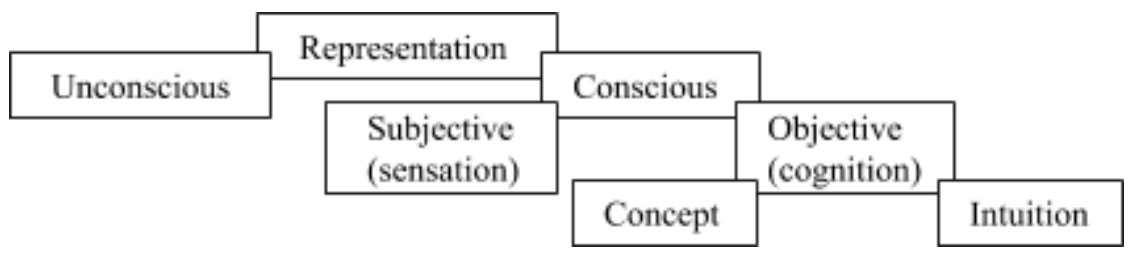

Retrieved from Janiak (2009)

Figure 1 shows that Kant regards our intuition as an objective, conscious representation. Intuition for Kant happens when we represent some $X$, such as an event, directly and without intermediaries. Journalists can represent the sanitary crisis in Brazil by indicating clearly and directly which event they are referring to such as the number of deaths from a specific locality in a particular period of time. This is different from making a conscious and objective representation of an event as a concept. An event is represented as a concept when we refer to it by using a mediated concept. We may represent the seriousness of a sanitary crisis by alluding to the editorial of a scientific journal. This paper argues that journalists, in order to expose manipulative language, ignorance and shallow thinking, should structure questions invoking the a priori intuition of authorities. Journalists are expected to make direct references to the forms of space and time in their critical inquiry to expose how authorities' personal experiences are mentally organized and classified. In the absence of literal forms of space and time, which may 
require prior knowledge, this paper suggests inquirers to ask direct and simple questions based on the propositions put forth by public authorities (see on Table 1 a list of 'a priori intuition' questions deprived of prior knowledge).

\section{Method}

The statement of the minister, questions asked by reporters, and the minister's answers are the object of analysis in this study. The objective is to assess the content of these statements and how they could be logically challenged without any prior knowledge of the crisis itself. Before starting the review of statements and proposed recommendations, it is necessary to provide an overview of the structure of the ten-minute statement.

The minister opens up outlining how the new ministry will address the covid-19 epidemic and the health system across the country. He divides the federal strategy into three areas: i) information; ii) infra-structure; and iii) national guidance for regional and local governments regarding mitigation measures for covid-19. By 'information', he starts off claiming that the government knows very little about the disease. This lack of knowledge creates barriers for making informed decisions, he adds. He points out some statistics that are necessary. He also stresses the importance of including under 'information', the number of sick people not infected with this pathogen. He expresses concern that other sick people have not been seeking treatments for their chronic diseases. He also stresses the importance of considering the plight of health insurance plans in the context of an economic fallout. He argues that economic downturn risks putting further stress onto the public health system. The minister then abruptly turns to the condition of hospitals. He briefly talks about getting them ready for covid-19 patients before revealing his concern for hospitals facing lower demand for other types of illnesses. He is worried about how hospitals will financially survive in this crisis. And the longer this crisis lasts, he warns, the harder it will be for hospital administrations. 
He continues explaining his concern to the no-treatment of no-covid-19 patients by predicting that another crisis is looming: that once this epidemic is over, hospitals will not be able to treat patients suffering from other diseases. He then states that the ministry is focused on the system despite the current discussion being mainly about covid-19. The minister then reveals that there is a sketch for the creation of a database with other ministries and the private sector.

In relation to 'infra-structure', he first hesitates. He briefly claims the ministry is planning something but then states that the problem is that the ministry is taking care of people today (sic). He then generally mentions hospitals, ventilators, intensive care units, human resources. He asks people to understand that the crisis is still unfolding. He uses an example in the United States to illustrate the unexpected shortage of medicines for patients being intubated. This example, he argues, serves to showcase that the Brazilian government is looking not only at what makes headlines but also at other details to provide care to patients. He then relates this topic to the announcement that he is working closely with a high-rank military official. He defends that having this army official in his office will increase the efficiency of how the health ministry operates. He then hesitates once again and quickly shifts to the third category of this briefing: 'national guidance for covid-19'.

He starts off using real and hypothetical statistics to compare and contrast people infected with the novel coronavirus and the sick with other diseases. He then mentions herd immunity and the timeline for the development of a vaccine, along with the non-exponential increase of infections, to imply that herd immunity could be the solution for this sanitary crisis in the country. He then forcefully states that it is impossible for a country to survive one or one year and a half if the economy shuts down. He says that isolation can be part of the initial response to the epidemic but not part of the exit strategy. It is this 'exit strategy', he adds, that the federal government will help state and local governments with.

Having finished the explanation of this outline, the minister cites some numbers to claim that Brazil is one of the best in the world in dealing with covid-19. He compares death per million in Brazil with statistics from Germany, France, Spain, the UK, and the US. He says the country has 
one of the best statistics in comparison with these countries. He adds that the problem with covid-19 is that it scares people because it creates a surge of demand for health systems. He then explains that health systems are not built to have idleness. Health systems need to work with maximum efficiency. 'Health is too expensive', he states. Based on this logic, hospitals work close to full capacity. Under these circumstances, he explains that when something overburdens the system, it is nearly impossible to adapt to the new norm at the same rate. He uses this rationale to back up once again the need to work closely with a high-rank military official. He summarizes this part of the briefing as being the new guidelines for the new Health Ministry.

He then resorts to more statistics to compare and contrast the rates for the infected, the dead and the recovered. He acknowledges the situation is difficult and complex but the government can overcome this challenge. And more importantly, he concludes, improve the health system after the covid-19 crisis is over.

The first question was made by a journalist from an outlet that supports the government (Filho, 2020). The reporter asks for examples of exit strategies and which localities could start implementing them.

The minister says he does not have an answer but can tell how the ministry will do it. He says that national guidelines for this strategy need another week to be refined. He believes that this timeline is reasonable considering that he has been in office for five days. He says that due to the size and complexity of the country, these exit strategies need to be locally tailored. He points to the metrics of possible new infected cases added by the past cases, the number of beds available, and the status of human resources. He then says that projections are very complex. He explains that mathematical models try to predict what will happen. He then cites the numbers from Imperial College for death rates and how these numbers could be substantially reduced with some sort of non-pharmaceutical intervention. He claims that the sharp reduction in this projection, as suggested by the model of Imperial College, is impossible. He says that mathematical models need to be standardized. The problem of models, even if they are 
methodologically correct, is that they largely depend on the premises they are designed with, he explains. The data used to run models determines the outcome. Thus, he states, we need to compare different models with different projections. And the main problem is that if the numbers of these projections are too alarming, and people start taking them for granted, the government risks increasing the fear and expectation of society. So, he says, the ministry will reveal its own model within a week for states and municipalities to use it for benchmark. The minister adds that the federal model will include different subgroups. He also states that the model needs to reflect reality accurately. He claims that models making long-term projections make too many mistakes. Thus the government needs to make short-term projections and quickly adapt if circumstances change. He argues that the government cannot guess what it is going to happen in the long term. 'This is impossible', he concludes.

The second question was asked by a reporter from a different television channel but also supportive of the current administration (Filho, 2020). The question asks the minister for his opinion on the risk of relaxing mitigation measures currently in place considering that it might lead to higher infection rates and to the collapse of regional health systems already operating close to full capacity.

The minister says that he does not believe that the number of infections and the surge in demand for hospitals will happen at the same time. He then adds that his job is to ensure that his plan will work out. He tells the reporter that these variables, in addition to the one the reporter mentioned about the possibility of being reinfected, make it harder to understand this disease. So the government is making an effort to understand this disease better. The government needs the number from each region to provide guidance to each locality. He wants people to understand that there is no magic bullet for this crisis. He claims that ideas to address this crisis are not inherently bad or good but poorly or well used. So, he states, 'we need wisdom to use what we have'. He cites the example of mass testing. 'There is no mass testing', he affirms citing South Korea, which, according to the minister, has conducted eleven thousand tests per million people. He says that this is not a population testing, this is not mass testing. What we need to do, he adds, 
is to ensure that the sample of our tests reflect the population. He then cites Italy, which, he says, conducted twenty-five tests per million, more than double of South Korea, and despite that, the crisis was a disaster in Italy. He wants to show the reporter that it is important to have wisdom to have data and interpret it to make informed decisions on the actions required to take. 'This is what will make every difference', he finalizes.

The third question was from a reporter from a third media network but also biased towards the incumbent president's opinion on reopening the economy (Folha de S. Paulo, 2020). The question is about mass testing and the relaxation of social isolation policies against the spread of the novel coronavirus particularly in Brasilia, the capital of the country.

The minister starts differentiating between the test for diagnosis and immunity tests. He states that each type of test has its limitations. The important strategy at the moment, he adds, is how the tests will be distributed. Then he adds that it is important, according to the model he mentioned earlier, to continuously monitor (unclear) to decide whether the strategy needs to be reviewed. He repeats that when 'you know little about something, you do not know what is going to happen, so you need to be fast enough to make a diagnosis and take action'. So, he says, that if something happens, the government should review its strategy. He then continues saying that if one does not master a subject, we need to test, and the capacity is to test and act', he explains. He adds: 'Test, monitor the effects of early interventions, and follow up on next steps'. He concludes saying that testing is not important but the decisions you make based on the test you have conducted.

\section{Results and Discussion}

The statement and answers provided by the minister, in addition to questions asked, highlighted three main aspects. First, the federal government openly favors the media channels amenable to the status quo narratives. Journalists from these channels asked general questions along the lines of the government's agenda. Second, the minister indicated that he is aligned with the president's 
opinion that the relaxation of isolation and social distancing should take effect as soon as possible. Third, the strategy of the federal government to reduce the risk of transmission for this pathogen is unclear. The newly appointed minister shows confusion, ignorance to international best practices, manipulative language and lack of understanding of scientific methods underlying contingency planning and decision making under uncertainty.

The assumptions behind statements and flaws in critical thinking by the minister and reporters need to be exposed for the enhancement of planning and decision making in crisis management. Kant's ideas on how the intuition of authorities, or their notions of space and time, affect their representation of reality provide a roadmap in this regard. Suggested questions listed below follow the idea of Kant that for our intuition to be an objective, conscious representation of reality, it is necessary that we make direct references to personal notions of space and time. Such references are expected to help the public grasp complexity while critically assessing political statements. The expectation is met if reporters asking questions i) put aside any prior knowledge about the subject and focus instead on logic and ii) 'personalize' every question so that the analysis of the problem reveals the boundaries in the rationality of the interviewee. 'Personalize' in this paper means resorting to notions of space and time that bring the problem in question as close as possible to the a priori intuition of the authority being questioned.

\section{Table 1}

\begin{tabular}{|l|l|l|l|}
\hline Statement & 'a priori intuition' question & Space & Time \\
\hline $\begin{array}{l}\text { The minister has been recently } \\
\text { appointed. }\end{array}$ & $\begin{array}{l}\text { What experiences do you have to lead the } \\
\text { country in this crisis? } \\
\text { How is your background different from the } \\
\text { previous health minister? }\end{array}$ & your background have & previous \\
\hline $\begin{array}{l}\text { The government knows very little } \\
\text { about the novel coronavirus and } \\
\text { covid-19. }\end{array}$ & What is your experience on pandemics? & your experience & pandemics \\
\hline $\begin{array}{l}\text { The need of some statistics to } \\
\text { make informed decisions. }\end{array}$ & $\begin{array}{l}\text { How many deaths do you think are necessary to } \\
\text { make up for enough data? }\end{array}$ & you think & enough \\
\hline $\begin{array}{l}\text { Present and future concern for } \\
\text { no-covid-19 patients. }\end{array}$ & $\begin{array}{l}\text { Can you tell what is the timeline and cost of } \\
\text { treating covid-19 patients? }\end{array}$ & you tell & timeline \\
\hline
\end{tabular}




\begin{tabular}{|c|c|c|c|}
\hline $\begin{array}{l}\text { Economic depression will affect } \\
\text { health insurance which in turn } \\
\text { will affect the public health } \\
\text { system. }\end{array}$ & $\begin{array}{l}\text { Do you know how many Brazilians right now } \\
\text { hold a private health insurance policy? }\end{array}$ & you know & right now \\
\hline $\begin{array}{l}\text { Getting hospitals ready to treat } \\
\text { covid-19 patients. }\end{array}$ & $\begin{array}{l}\text { Can you explain how you will help a public } \\
\text { hospital in a poor area get ready to treat covid-19 } \\
\text { patients? }\end{array}$ & you explain & $\begin{array}{l}\text { covid-19 } \\
\text { patients }\end{array}$ \\
\hline $\begin{array}{l}\text { Concern about hospitals not } \\
\text { surviving through this crisis. }\end{array}$ & $\begin{array}{l}\text { Is your concern in this crisis on private or public } \\
\text { hospitals? }\end{array}$ & your concern & this \\
\hline $\begin{array}{l}\text { Another crisis is looming: the } \\
\text { treatment of patients with other } \\
\text { chronic diseases. }\end{array}$ & $\begin{array}{l}\text { When do you think this crisis started in the } \\
\text { country and when it will be over? } \\
\text { Do you know if there are hospitals that can treat } \\
\text { covid- } 19 \text { and non-covid-19 patients at the same } \\
\text { time? }\end{array}$ & $\begin{array}{l}\text { you think } \\
\text { you know }\end{array}$ & $\begin{array}{l}\text { started/be } \\
\text { over } \\
\text { at the same } \\
\text { time }\end{array}$ \\
\hline $\begin{array}{l}\text { The ministry is focused on the } \\
\text { health system. }\end{array}$ & $\begin{array}{l}\text { How did you instruct your team to prioritize } \\
\text { tasks within this 'system'? }\end{array}$ & you instruct & prioritize \\
\hline $\begin{array}{l}\text { There is a plan to create a } \\
\text { database across the government } \\
\text { and with the help of the private } \\
\text { sector. }\end{array}$ & $\begin{array}{l}\text { Can you explain why this database has yet not } \\
\text { been ready? } \\
\text { Can you show how the other ministries will } \\
\text { contribute to this database? } \\
\text { Why do you think the federal government needs } \\
\text { the help of the private sector in creating this } \\
\text { database? }\end{array}$ & $\begin{array}{l}\text { you explain } \\
\text { you show } \\
\text { you think }\end{array}$ & $\begin{array}{l}\text { yet } \\
\text { will } \\
\text { this }\end{array}$ \\
\hline $\begin{array}{l}\text { The ministry is planning } \\
\text { something in terms of } \\
\text { infra-structure. }\end{array}$ & $\begin{array}{l}\text { Can you provide more details about this plan on } \\
\text { 'infra-structure'? }\end{array}$ & you provide & this \\
\hline $\begin{array}{l}\text { Under infra-structure, it was } \\
\text { mentioned hospitals, ventilators, } \\
\text { intensive care units, human } \\
\text { resources. }\end{array}$ & $\begin{array}{l}\text { What is your plan for each 'infra-structure' in the } \\
\text { next few weeks? }\end{array}$ & your plan & $\begin{array}{l}\text { in the next } \\
\text { few weeks }\end{array}$ \\
\hline $\begin{array}{l}\text { The federal government is looking } \\
\text { at all the details to provide care } \\
\text { during this crisis. }\end{array}$ & Can you tell what these other details are? & you tell & are \\
\hline $\begin{array}{l}\text { Decision to work closely with an } \\
\text { army official. }\end{array}$ & $\begin{array}{l}\text { Did you consider other candidates before making } \\
\text { this decision? }\end{array}$ & you consider & before \\
\hline $\begin{array}{l}\text { Key statistics needed such as the } \\
\text { rates for the infected, the dead and } \\
\text { the recovered. }\end{array}$ & $\begin{array}{l}\text { Can you explain why each of these statistics is } \\
\text { important? } \\
\text { Do you think these statistics reflect what is } \\
\text { happening? } \\
\text { Can you tell the stories that these statistics do not } \\
\text { show in this crisis? }\end{array}$ & $\begin{array}{l}\text { you explain } \\
\text { you think } \\
\text { you tell }\end{array}$ & $\begin{array}{l}\text { these } \\
\text { is happening } \\
\text { this }\end{array}$ \\
\hline $\begin{array}{l}\text { His plan for the ministry will } \\
\text { improve the health system once }\end{array}$ & $\begin{array}{l}\text { Can you anticipate how the health system will be } \\
\text { better once this crisis is over? }\end{array}$ & you anticipate & over \\
\hline
\end{tabular}




\begin{tabular}{|c|c|c|c|}
\hline this crisis is over. & & & \\
\hline $\begin{array}{l}\text { First reporter asked for examples } \\
\text { of exit strategies and localities } \\
\text { that could start implementing } \\
\text { these strategies. }\end{array}$ & $\begin{array}{l}\text { How would you instruct a small shop on safely } \\
\text { resuming operations? }\end{array}$ & you instruct & resuming \\
\hline $\begin{array}{l}\text { Informing the date when the } \\
\text { release of a national guideline on } \\
\text { how state and local governments } \\
\text { can implement exit strategies will } \\
\text { happen. He considered this } \\
\text { timeline reasonable. }\end{array}$ & $\begin{array}{l}\text { Can you share the challenges in releasing a } \\
\text { national guideline within this timeline? } \\
\text { Can you tell who the people are working on } \\
\text { designing this guideline? }\end{array}$ & $\begin{array}{l}\text { you share } \\
\text { you tell }\end{array}$ & $\begin{array}{l}\text { within } \\
\text { working on }\end{array}$ \\
\hline $\begin{array}{l}\text { The necessity for the national } \\
\text { guideline to be locally tailored. }\end{array}$ & $\begin{array}{l}\text { What do you think are the risks of leaving to } \\
\text { state and local governments to manage this } \\
\text { crisis? } \\
\text { How do you see the role of the federal } \\
\text { government in this crisis? } \\
\text { Do you think this national guideline can be } \\
\text { flexible and effective at the same time? } \\
\text { Are you considering international best practices } \\
\text { in the development of this guideline? }\end{array}$ & $\begin{array}{l}\text { you think } \\
\text { you see } \\
\text { you think } \\
\text { you considering }\end{array}$ & $\begin{array}{l}\text { this } \\
\text { this } \\
\text { at the same } \\
\text { time } \\
\text { this }\end{array}$ \\
\hline $\begin{array}{l}\text { The following metrics could be } \\
\text { incorporated into the upcoming } \\
\text { national guideline: possible new } \\
\text { infected cases added by the past } \\
\text { cases, the number of beds } \\
\text { available, and the status of human } \\
\text { resources. }\end{array}$ & $\begin{array}{l}\text { Can you explain how local governments in rural } \\
\text { areas can calculate 'possible new infected cases'? } \\
\text { Can you explain the reasons why 'new infected } \\
\text { cases' are added to 'past cases'? } \\
\text { Do you know if these are all the metrics to be } \\
\text { included in this national guideline? }\end{array}$ & $\begin{array}{l}\text { you explain } \\
\text { you explain } \\
\text { you know }\end{array}$ & $\begin{array}{l}\text { new } \\
\text { added } \\
\text { this }\end{array}$ \\
\hline $\begin{array}{l}\text { Being skeptical about a } \\
\text { non-pharmaceutical intervention } \\
\text { substantially reducing the number } \\
\text { of deaths. }\end{array}$ & $\begin{array}{l}\text { What is your experience in modelling to affirm } \\
\text { that it is impossible to believe in the projection } \\
\text { made by Imperial College? } \\
\text { Can you show what are the other models that the } \\
\text { government is using to support its decisions? }\end{array}$ & $\begin{array}{l}\text { your experience } \\
\text { you show }\end{array}$ & $\begin{array}{l}\text { projection } \\
\text { is using }\end{array}$ \\
\hline Models need to be standardized. & $\begin{array}{l}\text { Can you explain why models need to be } \\
\text { standardized and how you plan to do that? } \\
\text { Do you know if the models used by the } \\
\text { government are standardized? }\end{array}$ & $\begin{array}{l}\text { you explain } \\
\text { you know }\end{array}$ & $\begin{array}{l}\text { plan } \\
\text { are }\end{array}$ \\
\hline $\begin{array}{l}\text { The minister classifies as a } \\
\text { 'problem' the fact that models are } \\
\text { highly dependent on the premises } \\
\text { they are designed with. }\end{array}$ & $\begin{array}{l}\text { How would you make models less dependent on } \\
\text { the premises they are designed with? }\end{array}$ & you make & are \\
\hline $\begin{array}{l}\text { The federal government needs to } \\
\text { compare different models with } \\
\text { different projections. }\end{array}$ & $\begin{array}{l}\text { Why do you need to compare models if they are } \\
\text { to be standardized as you have just said? } \\
\text { Can you point to which models featuring } \\
\text { different projections the government is relying } \\
\text { on? }\end{array}$ & $\begin{array}{l}\text { you need } \\
\text { you point }\end{array}$ & $\begin{array}{l}\text { just } \\
\text { relying on }\end{array}$ \\
\hline
\end{tabular}




\begin{tabular}{|c|c|c|c|}
\hline & $\begin{array}{l}\text { Can you explain how you select the projections } \\
\text { of one model over another? }\end{array}$ & you explain & select \\
\hline $\begin{array}{l}\text { The main problem with the } \\
\text { projections is that if the numbers } \\
\text { are too alarming, the government } \\
\text { risks increasing the fear and } \\
\text { expectation of society. }\end{array}$ & $\begin{array}{l}\text { What are 'alarming numbers' for you in this } \\
\text { crisis? } \\
\text { Can you explain what causes these numbers to } \\
\text { increase or decrease? } \\
\text { Are you implying that 'alarming numbers' should } \\
\text { be omitted by the government? } \\
\text { Why do you think people fear these 'alarming } \\
\text { numbers'? } \\
\text { How can you reduce the public fear caused by } \\
\text { these 'alarming numbers'? }\end{array}$ & $\begin{array}{l}\text { for you } \\
\text { you explain } \\
\text { you implying } \\
\text { you think } \\
\text { you reduce }\end{array}$ & $\begin{array}{l}\text { this } \\
\text { these } \\
\text { should } \\
\text { these } \\
\text { these }\end{array}$ \\
\hline $\begin{array}{l}\text { The ministry will reveal its own } \\
\text { model within a week for states } \\
\text { and municipalities so they can use } \\
\text { it for benchmark. }\end{array}$ & $\begin{array}{l}\text { Why do you think this model will be better than } \\
\text { the one used by Imperial College? } \\
\text { Do you think states and municipalities have the } \\
\text { capacity to collect data, run this model and } \\
\text { interpret data from this upcoming federal model? } \\
\text { Can you explain how the output of these models } \\
\text { will help local authorities make informed } \\
\text { decisions? }\end{array}$ & $\begin{array}{l}\text { you think } \\
\text { you think } \\
\text { you explain }\end{array}$ & $\begin{array}{l}\text { used by } \\
\text { upcoming } \\
\text { will }\end{array}$ \\
\hline $\begin{array}{l}\text { The minister adds that the federal } \\
\text { model will include different } \\
\text { subgroups. }\end{array}$ & $\begin{array}{l}\text { Can you detail which subgroups will be } \\
\text { included? }\end{array}$ & you detail & will \\
\hline $\begin{array}{l}\text { The minister argues that models } \\
\text { must reflect reality accurately. }\end{array}$ & $\begin{array}{l}\text { The word model does not seem to imply reality. } \\
\text { Can you explain how the federal government } \\
\text { ensures that its model accurately reflects reality? }\end{array}$ & you explain & reality \\
\hline $\begin{array}{l}\text { Models making long-term } \\
\text { projections make too many } \\
\text { mistakes. }\end{array}$ & $\begin{array}{l}\text { What do you think are the risks of not making } \\
\text { long-term plans in this crisis? }\end{array}$ & you think & this \\
\hline $\begin{array}{l}\text { The federal government needs to } \\
\text { make short-term projections and } \\
\text { quickly adapt if circumstances } \\
\text { change. }\end{array}$ & $\begin{array}{l}\text { Can you explain the risks of relying exclusively } \\
\text { on short-term projections in this crisis? }\end{array}$ & you explain & this \\
\hline $\begin{array}{l}\text { The government cannot know } \\
\text { what is going to happen in the } \\
\text { long term. }\end{array}$ & $\begin{array}{l}\text { What is your understanding of 'long term' in this } \\
\text { crisis? } \\
\text { If you cannot predict what is going to happen in } \\
\text { the long term, how can you make decisions now } \\
\text { that will only have an impact in the long term? }\end{array}$ & $\begin{array}{l}\text { your understanding } \\
\text { you make }\end{array}$ & $\begin{array}{l}\text { this } \\
\text { now/long } \\
\text { term }\end{array}$ \\
\hline $\begin{array}{l}\text { The second reporter asks for the } \\
\text { minister's opinion on the } \\
\text { relationships between relaxing } \\
\text { mitigation measures and the risk } \\
\text { of higher infection rates leading to } \\
\text { the collapse of health systems. }\end{array}$ & $\begin{array}{l}\text { Have you visited any city recently that may have } \\
\text { struggled with the surge of patients to the public } \\
\text { health system? } \\
\text { What is your plan for reducing the risk of } \\
\text { transmission in vulnerable localities now? }\end{array}$ & $\begin{array}{l}\text { you visited } \\
\text { your plan }\end{array}$ & recently \\
\hline
\end{tabular}




\begin{tabular}{|c|c|c|c|}
\hline & $\begin{array}{l}\text { Have you recently visited a vulnerable } \\
\text { community to the novel coronavirus? } \\
\text { What is your plan for the wellbeing of vulnerable } \\
\text { communities in this epidemic? }\end{array}$ & $\begin{array}{l}\text { you visited } \\
\text { your plan }\end{array}$ & $\begin{array}{l}\text { recently } \\
\text { this }\end{array}$ \\
\hline $\begin{array}{l}\text { He does not believe that the } \\
\text { increase in the number of } \\
\text { infections and the surge demand } \\
\text { for hospitals will happen at the } \\
\text { same time. }\end{array}$ & $\begin{array}{l}\text { Why do you think the increase in the number of } \\
\text { infections and surge in demand for hospitals will } \\
\text { not happen at the same time? } \\
\text { Can you explain how the number of infections } \\
\text { increases in this crisis? } \\
\text { Can you show when the surge in demand for } \\
\text { hospitals could be expected? }\end{array}$ & $\begin{array}{l}\text { you think } \\
\text { you explain } \\
\text { you show }\end{array}$ & $\begin{array}{l}\text { will } \\
\text { this } \\
\text { could }\end{array}$ \\
\hline $\begin{array}{l}\text { The minister categorically poses } \\
\text { that his job is to ensure that his } \\
\text { plan will work out. }\end{array}$ & $\begin{array}{l}\text { Why do you feel so confident about a plan that } \\
\text { has not yet been tested? } \\
\text { Can you anticipate how many people will die if } \\
\text { your plan does not pan out? }\end{array}$ & $\begin{array}{l}\text { you feel } \\
\text { you anticipate }\end{array}$ & $\begin{array}{l}\text { yet } \\
\text { will }\end{array}$ \\
\hline $\begin{array}{l}\text { The federal government needs } \\
\text { numbers from each region to } \\
\text { provide guidance to each locality. }\end{array}$ & $\begin{array}{l}\text { Can you tell what happens if a region cannot } \\
\text { provide accurate numbers? }\end{array}$ & you tell & will \\
\hline $\begin{array}{l}\text { There is no magic bullet for this } \\
\text { crisis. }\end{array}$ & $\begin{array}{l}\text { Who do you think is expecting a magic bullet in } \\
\text { this crisis? } \\
\text { Are you aware of international best practices that } \\
\text { the federal government can learn from and } \\
\text { partner with in this crisis? }\end{array}$ & $\begin{array}{l}\text { you think } \\
\text { you aware }\end{array}$ & $\begin{array}{l}\text { this } \\
\text { this }\end{array}$ \\
\hline $\begin{array}{l}\text { Ideas to address this crisis are not } \\
\text { inherently bad or good but poorly } \\
\text { used or well used. }\end{array}$ & $\begin{array}{l}\text { Can you illustrate this reasoning with some bad } \\
\text { and good examples since the outbreak of this } \\
\text { epidemic? }\end{array}$ & you illustrate & since \\
\hline $\begin{array}{l}\text { The federal government needs } \\
\text { 'wisdom' to use what we have. }\end{array}$ & $\begin{array}{l}\text { Can you be specific about what you understand } \\
\text { by 'wisdom' in this crisis? } \\
\text { Can you point to the sources of 'wisdom' of the } \\
\text { federal government in managing this crisis? } \\
\text { Do you have this so-called 'wisdom' to manage } \\
\text { this crisis? } \\
\text { Can you list what the federal government has and } \\
\text { does not have to manage this crisis? }\end{array}$ & $\begin{array}{l}\text { you be specific } \\
\text { you point } \\
\text { you have } \\
\text { you list }\end{array}$ & $\begin{array}{l}\text { during } \\
\text { this } \\
\text { this } \\
\text { this }\end{array}$ \\
\hline $\begin{array}{l}\text { There is no mass testing in the } \\
\text { country. }\end{array}$ & $\begin{array}{l}\text { Can you explain why there is no mass testing in } \\
\text { the country right now? } \\
\text { Why do you think mass testing is important in } \\
\text { this crisis? } \\
\text { Do you know if there are limitations to mass } \\
\text { testing as a strategy to contain the spread of this } \\
\text { virus? }\end{array}$ & $\begin{array}{l}\text { you explain } \\
\text { you think } \\
\text { you know }\end{array}$ & $\begin{array}{l}\text { right now } \\
\text { this } \\
\text { this }\end{array}$ \\
\hline
\end{tabular}




\begin{tabular}{|c|c|c|c|}
\hline $\begin{array}{l}\text { There is a difference between } \\
\text { population testing and mass } \\
\text { testing. }\end{array}$ & $\begin{array}{l}\text { Can you explain the differences between these } \\
\text { tests and how they help in this crisis? }\end{array}$ & you explain & this \\
\hline $\begin{array}{l}\text { The sample of tests must reflect } \\
\text { the population. }\end{array}$ & $\begin{array}{l}\text { Can you show how the sample of tests reflect the } \\
\text { population? } \\
\text { Can you tell when these tests start? } \\
\text { Do you know when the results will be publicly } \\
\text { available? } \\
\text { Can you explain how the results of these tests } \\
\text { will inform decision making? } \\
\text { What do you think are the risks in making } \\
\text { decisions only based on the results of these tests? }\end{array}$ & $\begin{array}{l}\text { you show } \\
\text { you tell } \\
\text { you know } \\
\text { you explain } \\
\text { you think }\end{array}$ & $\begin{array}{l}\text { reflect } \\
\text { start } \\
\text { will } \\
\text { will } \\
\text { these }\end{array}$ \\
\hline $\begin{array}{l}\text { Italy 'was a disaster' despite } \\
\text { conducting more mass testing } \\
\text { than South Korea. }\end{array}$ & $\begin{array}{l}\text { What do you think went wrong in Italy then? } \\
\text { Why do you think South Korea did better than } \\
\text { Italy? } \\
\text { Are there other countries that you would like to } \\
\text { mention as positive and negative examples in } \\
\text { containing and mitigating the risks of this virus? } \\
\text { Can you point to other lessons that the Brazilian } \\
\text { federal government learned from international } \\
\text { best practices? }\end{array}$ & $\begin{array}{l}\text { you think } \\
\text { you think } \\
\text { you would like } \\
\text { you point }\end{array}$ & $\begin{array}{l}\text { then } \\
\text { did } \\
\text { this } \\
\text { international } \\
\text { best practices }\end{array}$ \\
\hline $\begin{array}{l}\text { The importance } \\
\text { of data interpretation for making } \\
\text { informed decisions. }\end{array}$ & $\begin{array}{l}\text { Do you mean data analysis? Can you explain the } \\
\text { difference? } \\
\text { Can you tell who in your team is in charge of } \\
\text { data collection and analysis and why this person } \\
\text { can be trusted? } \\
\text { Can you show how these analyses will inform } \\
\text { decision making? }\end{array}$ & $\begin{array}{l}\text { you mean } \\
\text { you tell } \\
\text { you show }\end{array}$ & $\begin{array}{l}\text { difference } \\
\text { in your team } \\
\text { will }\end{array}$ \\
\hline $\begin{array}{l}\text { Decisions based on data will } \\
\text { 'make every difference'. }\end{array}$ & $\begin{array}{l}\text { Do you know whether there are other indicators } \\
\text { that could help the federal government make } \\
\text { informed decisions in times of uncertainty? } \\
\text { What do you think the risks are of waiting for } \\
\text { making decisions only when enough and } \\
\text { accurate data is available? } \\
\text { Can you explain how you calculate the trade-offs } \\
\text { of your decisions in this crisis? }\end{array}$ & $\begin{array}{l}\text { you know } \\
\text { you think } \\
\text { you show }\end{array}$ & $\begin{array}{l}\text { times } \\
\text { available } \\
\text { this }\end{array}$ \\
\hline $\begin{array}{l}\text { The third reporter asks the } \\
\text { minister to talk more about mass } \\
\text { testing and the relaxation of social } \\
\text { isolation policies, particularly in } \\
\text { Brasilia. }\end{array}$ & $\begin{array}{l}\text { Can you explain how mass testing informs social } \\
\text { isolation policies expected to be enacted in } \\
\text { Brasilia in the next few days? }\end{array}$ & you explain & $\begin{array}{l}\text { in the next } \\
\text { few days }\end{array}$ \\
\hline $\begin{array}{l}\text { It is important to closely monitor } \\
\text { (unclear) }\end{array}$ & $\begin{array}{l}\text { Can you tell again what needs to be closely } \\
\text { monitored in this crisis? }\end{array}$ & you tell & this \\
\hline
\end{tabular}




\begin{tabular}{|l|l|l|l|}
\hline $\begin{array}{l}\text { to decide whether the strategy } \\
\text { needs to be reviewed. }\end{array}$ & $\begin{array}{l}\text { Can you explain how this monitoring happens? } \\
\text { Can you tell when this monitoring indicates that } \\
\text { a strategy needs to be reviewed? }\end{array}$ & you tell explain & this \\
& Can you explain how this review process works? & you explain & this \\
\hline
\end{tabular}

Table 1 shows questions that could be asked based on statements made by the minister and questions asked by reporters. This list of 'a priori intuition' questions aims to move to the forefront how the mind of the interviewer organizes and classifies personal experiences, which is a central premise of Kant's argument. By gaining insights into and exposing how a particular mind influences thoughts, journalists help the public assess the reliability and validity of authoritative arguments.

In this discourse analysis, it is observed that reporters have not resorted to this strategy in their questioning. As for the minister's briefing and his answers, it is unclear the depth of his critical thinking skills and his ability to lead this crisis. Journalists asking 'personal' questions that had revealed the minister's 'a priori intuition' would have accelerated this assessment and as a result helped the public evaluate more confidently whether the proposed policies were well thought out and could be trusted.

\section{Conclusion}

Public trust in decision and policy making is particularly important in times of crisis and uncertainty. People generally look for dependable information and clear guidance on how to act to reduce the risks of a threat to themselves. Journalists asking questions that expose how public authorities' personal experiences determine the organization and classification of their thoughts contribute in this regard. Straightforward questioning that invokes the notions of space and time has the ability to showcase the level of thoughtfulness in critical thinking. Readers and viewers are more likely to make better decisions and comply with ad hoc policies if they are exposed 
with facts that are clearly displayed, contrasted and contextualized ${ }^{12}$. Kant's epistemology of transcendental idealism can guide the 'personalization' of this inquiry process.

The proposed inquiry process features limitations. First, this 'personalization' may come across as inappropriate in some instances. Thus it needs to be adapted to cause less friction and allow the interviewer to obtain critical information while exposing a particular reasoning accordingly. Second, the interpretation of the work of Kant has been the focus of many debates. Thus this study understands that there could be alternative interpretations to the way the notions of space and time were instrumentally proposed in this study. Third, the circumstances under which authorities and journalists operate are different than those that scholars and scientists are used to. Thus it is reasonable to expect that not every question can be asked as well as satisfactorily answered.

\section{Acknowledgement}

No conflict of interest to report. No funding to declare.

\section{References}

Albarran, A. B. (2008). Media economics. The International Encyclopedia of Communication.

Allison, H. E. (2006). Kant's transcendental idealism. A companion to Kant, 111424.

Anspach, N. M., \& Carlson, T. N. (2018). What to believe? Social media commentary and belief in misinformation. Political Behavior, 1-22.

Bardoel, J. L. H., \& d'Haenens, L. S. J. (2004). Media responsibility and accountability: New conceptualizations and practices.

\footnotetext{
1 The new Health Minister has not provided a national guideline that state and local authorities could agree after more than three weeks have passed since the first public briefing (Rezende, 2020).

2 The new Health Minister quit his position in the federal government on May 15th, 2020, less than a month after taking office. He left praising social distancing policies enacted by governors and mayors. The media claims he grew increasingly uncomfortable with the president's desire to widely use chloroquine as a treatment to covid-19 (Zylberkan, 2020).
} 
Barnett, S. (2009). Journalism, democracy and the public interest. Reuters Institute for the Study of Journalism, Department of Politics and International Relations, University of Oxford.

Behnke, E. (2020, April 29). 'Não vão botar no meu colo essa conta', diz Bolsonaro sobre mortes pelo coronavírus. Estadão. Retrieved from

https://politica.estadao.com.br/noticias/geral,nao-vao-botar-no-meu-colo-essa-conta-diz-bolsonar o-sobre-mortes-pelo-coronavirus, 70003286981

Brandão, V. (2020, April 14). Confundir para dividir: a loucura consciente de Bolsonaro frente ao coronavírus. Observatório da Imprensa. Retrieved from

http://www.observatoriodaimprensa.com.br/conjuntura-politica/confundir-para-dividir-a-loucura -consciente-de-bolsonaro-frente-ao-coronavirus/

Brook, A. (2010). Kant's View of the Mind and Consciousness of Self. Stanford encyclopedia of philosophy.

Caple, H., \& Bednarek, M. (2013). Delving into the discourse: Approaches to news values in journalism studies and beyond.

Congresso Em Foco (2020, April 1). "Gripezinha" e "histeria": cinco vezes em que Bolsonaro minimizou o coronavírus. UOL. Retrieved from

https://congressoemfoco.uol.com.br/governo/gripezinha-e-histeria-cinco-vezes-em-que-bolsonar o-minimizou-o-coronavirus/

Durfee, J. L. (2006). "Social change" and "status quo" framing effects on risk perception: An exploratory experiment. Science Communication, 27(4), 459-495.

Ferguson, N., Laydon, D., Nedjati Gilani, G., Imai, N., Ainslie, K., Baguelin, M., ... \& Dighe, A. (2020). Report 9: Impact of non-pharmaceutical interventions (NPIs) to reduce COVID19 mortality and healthcare demand. Imperial College London. Retrieved from https://dsprdpub.cc.ic.ac.uk:8443/handle/10044/1/77482

Fisher, C. (2018). What Is Meant By 'Trust'In News Media?. In Trust in Media and Journalism (pp. 19-38). Springer VS, Wiesbaden.

Filho, J. (2020, February 23). Bolsonaro se diz perseguido pela imprensa. Mas Band, SBT, Record e Rede TV estão ao seu lado. The Intercept. Retrieved from https://theintercept.com/2020/02/23/imprensa-bolsonaro-band-sbt-record-rede-tv/ 
Folha de S. Paulo (2020, February 27). Bolsonaro elogia CNN Brasil e defende boicote a mídia 'que mente'. Folha. Retrieved from https://www1.folha.uol.com.br/poder/2020/02/bolsonaro-elogia-cnn-brasil-e-defende-boicote-amidia-que-mente.shtml

Folha de S. Paulo (2020a, April 30). Veja declarações de Bolsonaro minimizando coronavírus diante de escalada de mortes. Folha. Retrieved from https://www1.folha.uol.com.br/equilibrioesaude/2020/04/veja-declaracoes-de-bolsonaro-minimiz ando-coronavirus-diante-de-escalada-de-mortes.shtml

Gomes, W. J. F. (2020, March 31). Jair Bolsonaro e a desinformação a serviço da covid-19. Observatório da Imprensa. Retrieved from http://www.observatoriodaimprensa.com.br/coronavirus/jair-bolsonaro-e-a-desinformacao-a-serv ico-da-covid-19/

IstoÉ (2020, April 24). Insper: Bolsonaro é líder disfuncional que age contra interesses de quem o elegeu. Istó́ Dinheiro. Retrieved from

https://www.istoedinheiro.com.br/insper-bolsonaro-e-lider-disfuncional-que-age-contra-interesse s-de-quem-o-elegeu/

Janiak, A. (2009). Kant's views on space and time. Stanford Encyclopedia of Philosophy.

Klayman, J. (1995). Varieties of confirmation bias. Psychology of learning and motivation, 32, $385-418$.

Knobloch-Westerwick, S., \& Kleinman, S. B. (2012). Preelection selective exposure: Confirmation bias versus informational utility. Communication Research, 39(2), 170-193.

McLaughlin, P., \& Schlaudt, O. (2020). Kant's Antinomies of Pure Reason and the 'Hexagon of Predicate Negation'. Logica Universalis, 1-17.

McLear, C. (2017). Intuition and presence. In Andrew Stephenson \& Anil Gomes (eds.), Kant and the Mind. Oxford: Oxford University Press. pp. 86-103 (2017).

Merritt, M. M. (2010). Kant on the Transcendental Deduction of Space and Time: an essay on the philosophical resources of the Transcendental Aesthetic. Kantian Review, 14(2), 1-37. 
Nisbet, M. C., \& Fahy, D. (2015). The need for knowledge-based journalism in politicized science debates. The ANNALS of the American Academy of Political and Social Science, 658(1), 223-234.

O Globo (2020, January 28). A falta de preparo do Brasil para enfrentar o coronavírus e o embate entre Moro e Bolsonaro. Globo. Retrieved from https://oglobo.globo.com/podcast/a-falta-de-preparo-do-brasil-para-enfrentar-coronavirus-o-emb ate-entre-moro-bolsonaro-24216068

Picheta, R.; Siad, A. (2020, May 14). Bolsonaro's March visit with Trump was a 'corona trip,' says Brazil's former health secretary. $C N N$. Retrieved from https://edition.cnn.com/2020/05/13/americas/bolsonaro-us-visit-corona-trip-intl/index.html

Pluviano, S. (2019). On the fallibility of human memory for future actions. Edinburgh Research Archive. The University of Edinburgh.

Prado, B. (2020). COVID-19 in Brazil:“'So what?”. TheLancet, 395(10235), 1461.

Rezende, C. (2020, March 13). Estados e municípios negam plano de isolamento e Teich cancela apresentação. UOL. Retrieved from

https://noticias.uol.com.br/colunas/constanca-rezende/2020/05/13/estados-negam-plano-de-isola mento-do-governo-e-teich-cancela-apresentacao.htm

Ribeiro, M. (2020). Bolsonaro diz que desemprego não pode ser efeito colateral da crise. Agência $O$ Globo. Retrieved from https://economia.ig.com.br/2020-03-24/bolsonaro-diz-que-e-preciso-brigar-para-que-desemprego -nao-seja-efeito-colateral-da-crise.html

Scott, M. (2016). Theoretical Reason: Knowledge and its Limits in Immanuel Kant's Critique of Pure Reason. Limits, 23.

Starkey, G. (2006). Balance and bias in journalism: Representation, regulation and democracy. Palgrave.

Strawson, P. (2018). The bounds of sense: An essay on Kant's critique of pure reason. Routledge.

Street, J. (2010). Mass media, politics and democracy. Macmillan International Higher Education. 
UOL (2020, April 22). Novo Ministro da Saúde Nelson Teich Participa Pela Primeira Vez de Coletiva do Governo Federal. UOL. Retrieved from

https://www.youtube.com/watch?v=R81kH5XwELM

Van Dalen, A. (2012). Structural bias in cross-national perspective: How political systems and journalism cultures influence government dominance in the news. The International Journal of Press/Politics, 17(1), 32-55.

van Zoonen, W., \& van der Meer, T. (2015). The importance of source and credibility perception in times of crisis: Crisis communication in a socially mediated era. Journal of public relations research, 27(5), 371-388.

Weterman, D. (2020, March 25). 'Uma gripe qualquer em minha mãe pode ser fatal', diz Bolsonaro. Estadão. Retrieved from

https://saude.estadao.com.br/noticias/geral,uma-gripe-qualquer-em-minha-mae-pode-ser-fatal-di z-bolsonaro, 70003247391

Williams, A. E. (2012). Trust or bust?: Questioning the relationship between media trust and news attention. Journal of Broadcasting \& Electronic Media, 56(1), 116-131.

Wood, A. W. (2007). Kantian ethics. Cambridge University Press.

Zylberkan, M. (2020, May 15). Nelson Teich pede demissão do Ministério da Saúde. Veja. Retrieved from https://veja.abril.com.br/brasil/ministro-nelson-teich-pediu-demissao/. 